DOI: 10.15503/onis2012-207-218

\title{
ZACHOWANIA ANTYSPOŁECZNE W UJĘCIU PSYCHODYNAMICZNYM
}

\author{
LiLIANa KolodZIejCZAK \\ liliana.kolodziejczak@gmail.com
}

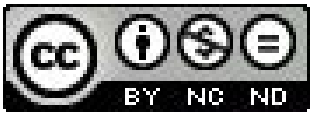

Paradygmat psychodynamiczny, choć wciąż dla niektórych brzmi nieco egzotycznie i obco, odbił się znacząco w wielu dziedzinach nauki, m.in. w: psychiatrii, psychologii, neurobiologii (neuroscience), kryminologii czy resocjalizacji.

Wielu uważa, że podejście psychodynamiczne jest jedynie dziedzina, która z rzetelną nauką nie może stanąć ramię w ramię. Jak wynika z najnowszych badań Jonathana Shedlera z Uniwersytetu w Kolorado przekonanie, że psychodynamice brakuje wsparcia empirycznego w żadnym razie nie zgadza się z istniejącymi dowodami naukowymi. J. Shedler zwraca także uwagę na to, iż te błędne założenia krytyków mogą być wynikiem wybiórczego rozpowszechniania badań naukowych ${ }^{1}$. Pojęcie paradygmatu psychodynamicznego jest szersze od samej psychoanalizy, natomiast trzeba pamiętać, że to właśnie psychoanaliza stworzyła bazę dla wszelkich oddziaływań terapeutycznych, które postaram się omówić. W zawodach, które są związane z troską o zdrowie psychiczne jednostek, niejednokrotnie można się spotkać z awersją do zarozumiałości psychoanalityków i ich od dawna ugruntowanego, niczym niepodważanego autorytetu². Stynny żart o tym, jakoby psychoanalityk to taki ktoś, kto tylko udaje, że nie wie wszystkiego, jest tego znakomitym przykładem.

Szukając początków podejścia psychodynamicznego, natkniemy się m.in. na takie postacie, jak: Gottfried Wilhelm Leibniz, Gustav Theodor Fechner, Hughlings Jackson i oczywiście Zygmunt Freud ${ }^{3}$. Pierwszym, który użył pojęcia nieświadomość, był G. Leibniz, zmieniając tym samym nie tylko myślenie ówczesnych filozofów, ale także zapisując się na kartach historii psychiatrii. Z kolei G. Fechner, fizyk i filozof, wdrożył określenie psychodynamiczny, które miało się przeciwstawiać statyczności, niezmienności. Pojęcie było używane przez samego Z. Freuda i choć później straciło na swej popularności, wróciło do łask dzięki współczesnym neurobiologom4.

Aktualnie, teorie psychodynamiczne przedstawiane są za pomocą modelu konfliktu bądź modelu deficytu. Pierwszy dotyczy wyjątkowo silnych mocy aktywnie działających w umyśle. Wspomniane siły żądają realizacji swoich pragnień i jednocześnie znajdują się pod kontrolą innych, antagonistycznych sit, które nie chcą dopuścić do ich urzeczywistnienia. Drugi model zasadza się na przypuszczeniu, że człowiek z różnorodnych przyczyn cierpi na osłabienie lub nawet brak pewnych struktur psychicznych i dlatego niejednokrotnie, $\mathrm{w}$ celu utrzymania równowagi psychicznej, ma niedorzeczne oczekiwania względem innych osób. Doprowadza to do tego, że w pacjencie tkwią pewne reprezentacje psychiczne dotyczące zarówno siebie, jak i innych, i właśnie te reprezentacje stają się podbudową do kreowania swojej wizji świata ${ }^{5}$.Jak już wcześniej było wspomniane, wiele osób uważa psychoanalizę za niewiarygodna, z punktu widzenia naukowego. Zapomina się jednak, że twórcą psychoanalizy był nie tylko psychiatra, ale i neurolog, który

\footnotetext{
J. Shedler, The Efficacy of Psychodynamic Psychotherapy, "American Psychologist” 2010, nr 65, s. 98.

Tamże.

G. Gabbard, Psychiatria psychodynamiczna w praktyce klinicznej, Kraków 2009, s. 17.

4 P. Drozdowski, Psychoterapia psychodynamiczna, http://www.kcp.krakow.pl/materialy/psychoterapia-psychody-

5 G. Gabbard, Psychiatria psychodynamiczna..., dz. cyt., s. 17 - 18.
} namiczna, 20.12.2011. 
już w 1920 r. pisał, że „biologia jest krainą nieograniczonych możliwości. Możemy oczekiwać, że dzięki niej uzyskamy najbardziej zaskakujące informacje i jednocześnie nie możemy odgadnąć, jak nam odpowie za kilkanaście lat na teraz stawiane pytania. Może być tak, że zdmuchnie, jak świeczkę, wszystkie nasze nieprawdziwe hipotezy"6. Tak, więc psychodynamika nie może istnieć w oderwaniu od neurobiologii, gdyż umieszcza się ją w obrębie psychiatrii biopsychospołecznej. Definicja psychiatrii psychodynamicznej również podkreśla tę konieczność: „Psychiatria psychodynamiczna jest taką koncepcją procesu diagnozy i terapii, w której myśli się o pacjencie i klinicyście w kategoriach nieświadomych konfliktów, deficytów, zniekształconych struktur wewnątrzpsychicznych i relacji z obiektem wewnętrznym, a także uwzględnia współczesne dokonania w dziedzinie neuroscience" ${ }^{\prime \prime}$. Ten aspekt jest wyjątkowo istotny jeśli zastanawiamy się nad determinantą zachowań przestępczych u jednostki. Silne urazy psychiczne powodują zmiany w funkcjonowaniu mózgu, a te często diagnozuje się u osób antyspołecznych.

Niezaprzeczalnie, największe znaczenie dla podejścia psychodynamicznego miał Z. Freud. Choć trudno znaleźć osobę obojętną wobec jego poglądów, trudno zaprzeczyć, że posiadał dar myślenia teoretycznego oraz bogatą wyobraźnię, która pozwalała mu konstruować często trafne hipotezy. Ponadto, ten najsłynniejszy psychiatra posiadał wyjątkowo złożony temperament i cechy osobowości, które uczyniły go śmiałym badaczem. W przypadku, gdy dostrzegał, że jego teoria się nie potwierdza, potrafił z pokorą przysiąść do jej zmieniania. Nigdy jednak wspomniane modyfikacje nie były natychmiastowe. Podchodził do nich spokojnie i rozważnie, aby nie popełnić kolejnego błędu' ${ }^{8}$. Dwa podstawowe założenia psychoanalizy zostały sformułowane w gabinecie neurologa w czasie leczenia osób histerycznych, a stało się to dzięki metodzie przypominania sobie zapomnianych wydarzeń, przeżyć, doświadczeń:

„Aktywność umysłowa nie jest przypadkowa, ponieważ każdy proces umysłowy powiązany jest z myślami i wydarzeniami, które go poprzedzaja, czyli tak zwany psychiczny determinizm.

Większa część aktywności umysłowej przebiega poza świadomością ludzka, czyli w dynamicznej nieświadomości"'.

Nadawanie znaczenia na pozór przypadkowym objawom uczyniło psychiczny determinizm atrakcyjną hipoteza, ponieważ dzięki niemu można interpretować to, co wcześniej wydawało się absolutnie niewytłumaczalne i abstrakcyjne ${ }^{10}$. Można zatem uznać, że „ludzie są świadomie zdezorientowani i nieświadomie sterowani"11. Wiarygodność tego przekonania wspierały kliniczne wyzdrowienia, które prawdopodobnie zawdzięczały swoje efekty komunikowaniu pacjentowi znaczenia jego objawów. Wszystkim uczuciom, zachowaniom, snom czy pomyłkom można przypisać określone zachowanie. Zakładając, że istnieje psychiczny determinizm, musimy również uznać istnienie dynamicznej nieświadomości ${ }^{12}$. „Jeśli cała psychiczna aktywność powiązana jest z innymi procesami umysłowymi, ale większość z tych powiązań nie jest dla nas dostrzegalna, to w takim razie musi istnieć świat aktywności psychicznej, który nie jest dostępny naszemu wglądowi $^{\prime \prime 13}$. Te dwie podstawowe zasady wciąż pozostają fundamentem teorii psychodynamicznych.

6 G. Heilbrunn, Biologic Correlates of Psychoanalytic Concepts, "Journal of the American Psychoanalytic Association" 1979, nr 27, s. 597.

G. Gabbard, Psychiatria psychodynamiczna..., dz. cyt., s. 18.

G. Greenson, The Technique and Practice of Psychoanalysis, New York 1967, s. 14.

D. Bienenfeld, Psychodynamic Theory for Clinicians, Philadelphia 2006, s. 9.

Tamże.

11 G. Gabbard, Psychiatria psychodynamiczna..., dz. cyt., s. 25.

2 D. Bienenfeld, Psychodynamic Theory..., dz. cyt., s. 9.

3 Tamże. 
Pierwsze swoje doświadczenia Z. Freud zawarł w dobrze znanej teorii trzech systemów: świadomości (Św), przedświadomości (PŚw) i nieświadomości (NŚw), które mają odzwierciedlać poszczególne poziomy funkcjonowania psychiki. Te trzy systemy wchodzą w skład modelu topograficznego psychiki ${ }^{14}$. Nieświadome treści psychiczne znajdują się w: przedświadomości (materiał z tego miejsca można transmitować do systemu świadomości) oraz w nieświadomości (stąd trudno wydobyć pożądane treści, gdyż trudny materiał znajdujący się w tym miejscu został ocenzurowany i wyparty $)^{15}$. Model topograficzny, sam w sobie, nie przedstawia jak działają popędy i co kieruje ruchem między systemami, ale w sposób bardzo klarowny opisuje go D. Bienenfeld (2006).

Drugim modelem zaproponowanym przez Z. Freuda był model strukturalny, którego składnikami są: id, ego i superego. Zapoznanie się z nimi jest konieczne do zrozumienia większości teorii psychodynamicznych:

Id - nie ma bardziej prymitywnej struktury psychicznej. Id jest instancją nieświadomą i wewnątrzpsychiczną. Na tę strukturę składają się pierwotne pochodne popędu seksualnego i agresywnego. Ukształtował się w najwcześniejszym okresie rozwoju umysłowego, dlatego też ma charakter niewerbalny. Id nie ma poczucia czasu i nie tworzy chronologicznej narracji, ponieważ kształtuje się jeszcze przed rozwojem pamięci. Id jest nieustannie kontrolowane przez nieświadomą część ego oraz przez superego.

Zadaniem ego jest zaspokoić pragnienia id. Czyni to bezpośrednio, jeśli to możliwe, bądź też pośrednio - odraczając realizację potrzeby. Ego kontroluje także funkcje motoryczne, a jego umiejętności poznawcze umożliwiają rozwój pamięci. Świadoma część ego jest odpowiedzialna za podejmowanie decyzji oraz konsolidację wszystkich danych zmysłowych. Z kolei nieświadomy aspekt ego zawiera mechanizmy obronne, takie jak: wyparcie, regresja, projekcja, somatyzacja $i$ in. Mechanizmy te mają za zadanie bronić ego przed nachalnymi, prymitywnymi żądaniami $i d$.

Superego jest w większej części nieświadome, jednakże istnieją również świadome aspekty w tej strukturze. Superego jest, bardziej niż ego, wrażliwe na potrzeby id, dlatego musi być dużo mocniej zanurzone w nieświadomości. Na superego składają się nie tylko ideały ego, ale także sumienie, które na wzór rodzica zakazuje realizacji niedopuszczalnych pragnień. Ukształtowane superego pojawia się dopiero po rozwiązanej sytuacji edypalnej ${ }^{16}$.

Rys. 1 klarownie przedstawia rozłożenie opisanych już instancji psychicznych w uproszczonym modelu topograficznym.

Anna Freud, w związku z modelem strukturalnym, stwierdziła, że oddziaływania psychoanalityczne powinny uderzać w ego, gdyż tylko ta instancja może bezpośrednio dotrzeć do prymitywnego $i d$, do wyczulonego na jego potrzeby superego, a także do świata zewnętrznego. Zatem celem psychoterapii będzie sprawić, aby ego zrezygnowało z prymitywnych obron, a zastąpiło je bardziej subtelnymi, dojrzałymi ${ }^{17}$, takimi na przykład, jak sublimacja.

Warto jeszcze wspomnieć o znaczącym problemie teorii psychodynamicznych, który polega na notorycznym stawianiu znaku równości pomiędzy psychodynamiką a psychoanalizą. Krytycy uważają psychoanalizę za jednolity twór, zintegrowany myślowo i teoretycznie. Nic jednak bardziej mylnego! „Współczesna psychoanaliza jest wyjątkowo zróżnicowana i nie można mówić o spójnej szkole myśli. Można jednak uznać, że psychoanaliza jest, jak uniwersytet, który ma swój własny kierunek, lecz różne teorie, które koegzystują ze sobą w zawiłej i skomplikowanej relacji”"18.

14 S. Freud, Poza zasada przyjemności, Warszawa 2005, s. 59 - 63.

15 G. Gabbard, Psychiatria psychodynamiczna ..., dz. cyt., s. 21.

16 Tamże, s. 42, D. Bienenfeld, Psychodynamic Theory..., dz. cyt., s. 11.

17 G. Greenson, The Technique and ..., dz. cyt., s. 28.

18 S. Mitchell, M. Black, Freud and Beyond. A History of Modern Psychoanalytic Thought, New York 1995, s. 134. 
Rys. 1. Model strukturalny.

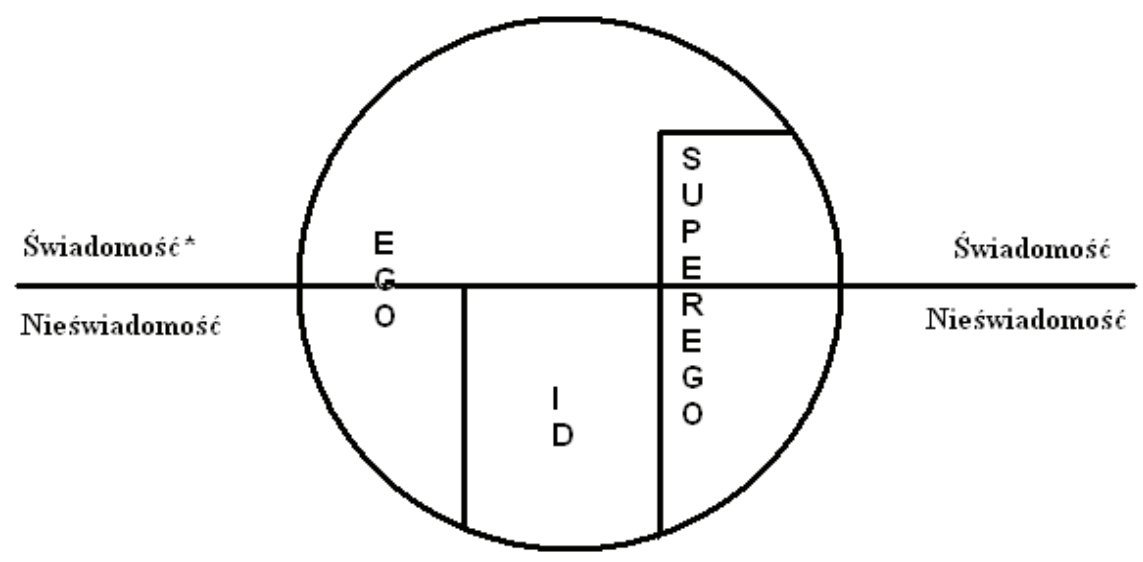

* Przedświadomość została usunięta w celu uproszczenia schematu.

Źródło: G. Gabbard, Psychiatria psychodynamiczna w praktyce klinicznej, Kraków 2009, s. 43.

Podejście psychodynamiczne okazało się byćfenomenem w resocjalizacji. Dzięki temu konstruktowi teoretycznemu ustala się przyczyny różnorodnych form dewiacji wychowanków w ośrodkach poprawczych, czy też osadzonych w zakładach karnych. Osoby z problemami antyspołecznymi zostały najgruntowniej przebadane, jednakże klinicyści do żadnej grupy pacjentów nie żywią tak dużej niechęci, jak do tej. Przyczyny tej awersji są dość oczywiste - jednostki silnie antyspołeczne $\mathrm{w}$ trakcie procesu terapeutycznego będą sięgać do wyjątkowo podstępnych zachowań, a oszustwa i zastraszanie terapeuty mogą stać się rutyną $a^{19}$. Innym powodem, dla którego terapeuci wystrzegają się takich pacjentów, jest znikomy efekt ich wyjątkowo trudnej pracy. Zachowania przestęp cze mają wyjątkowo złożoną etiologię, toteż nie możemy mówić o wyleczeniu pacjenta, a jedynie o poprawieniu jego sytuacji, która ma się odnosić do lepszej jego adaptacji do życia społecznego.

A. Sarason umiejętnie, w jednym zdaniu, ukazuje „urodę" psychodynamiki pisząc, że „Wszelkie dające się obserwować cechy zachowania mają swe wewnętrzne (ukryte) uwarunkowania" ${ }^{\prime 20}$. W umyśle dorosłego człowieka można odnaleźć wszystko to, co złożyło się na jego rozwój-każde pragnienie, każdy uraz psychiczny, każdą frustrację. Trudności osób pracujących z jednostkami przestępczymi zasadzają się na tym, że „najgłębiej wypierane są skłonności antyspołeczne. Na poziomie biologicznym jednostka odtwarza proces rozwoju rasy ludzkiej (...). W nieświadomości odnajdujemy wyparte fazy, które obserwujemy też u ludów prymitywnych: kanibalizm i skłonności mordercze. Ta prymitywna część osobowości stoi w jawnej sprzeczności z częścią cywilizowaną i ona właśnie podlega wyparciu"21.

Melanie Klein uważała, że superego pojawia się u dziecka około drugiego roku życia, ponieważ już wtedy mały człowiek ma za sobą wiele istotnych faz rozwojowych. Do tych faz należy zaliczyć przede wszystkim utrwalenia oralne (oralno-ssące oraz oralno-gryzące, które dotyczą tendencji kanibalistycznych) i utrwalenia analno-sadystyczne. Te ostatnie wiążą się z odczuwa-

19 G. Gabbard, Psychiatria psychodynamiczna ..., dz. cyt., s. 460.

20 K. Pospiszyl, Przestępstwa seksualne, Warszawa 2005, s. 16.

21 M. Klein, Miłość, poczucie winy i reparacja oraz inne prace z lat 1921 - 1945, Gdańsk 2007, s. 170. 
niem przyjemności z pobudzania sfery analnej, i z czynności wydalniczych ${ }^{22}$. Jaki może być wynik niepoprawnego przejścia przez wyżej wspomniane fazy rozwojowe? Przykładowo, osoby zafiksowane na fazie analno-sadystycznej będą czerpać przyjemność z okrucieństwa i możliwe, że wkroczą na drogę przestępcy seksualnego. Z. Freud zakładał, że „nerwica jest negatywem perwersji. Podczas gdy nerwica rodzi się ze stłumienia, w perwersjach infantylne zainteresowania seksualne są świadome i pozostają zaspokojone"23. Kazimierz Pospiszyl wskazuje, jak należałoby pracować z osobą perwersyjną: „poprzez stopniową neurotyzację, rozumianą jako nasycenie lękiem patologicznych, perwersyjnych skłonności seksualnych, doprowadzić można do znacznego wyhamowania tych negatywnych zachowan'”24. Pozostając przy fiksacji analno-sadystycznej, o której pisała M. Klein, nie można nie wspomnieć o spostrzeżeniach Z. Freuda, które dotyczyły sadyzmu i masochizmu. „Kto doznaje rozkoszy w sytuacji, gdy w stosunku seksualnym przysparza bólu drugiej osobie, ten jest też zdolny samemu smakować ból jako rozkosz - ból zrodzony w relacjach seksualnych. Sadysta zawsze jest jednocześnie masochistą ${ }^{\prime 25}$. Dzieje się tak zazwyczaj w wyniku agresji, której jednostka stała się ofiarą. Jeśli osobie nadużytej nie uda się wyprzeć traumatycznego wydarzenia, z biegiem czasu może stać się na tyle silna, by zacząć czerpać satysfakcję z sadyzmu, jakim obdarza innych. W ten właśnie sposób masochista staje się sadystą ${ }^{26}$. Pierwsze lata życia człowieka są dla psychoanalityków najistotniejszym czasem, dlatego omawiane w tym artykule teorie będą dotyczyć dzieci, które na skutek niepomyślnych zdarzeń życiowych stają się w przyszłości jednostkami antyspołecznymi.

W ramach ustalania przyczyn zachowań antyspołecznych, nie można również zapomnieć o czynnikach biologicznych, które będą determinować dziecko od samego początku i mogą utrudniać jego rozwój. Przykładowo, dziecko może przeżywać trudności w wyciszaniu się w relacji z matką. Nieprzespane noce malca, jego płacz i krzyk sprawiaja że matka inaczej go odbiera, niż gdyby było spokojne - miewa go dosyć, jest sfrustrowana i niechętna. Takie dzieci często nie mają uwewnętrznionego obrazu matki, przez co nie umieją się samouspokajać. To może być początkiem rozwoju reakcji patologicznych ${ }^{27}$.

M. Klein niemal całe swoje życie spędziła na obserwacji i analizie dzieci. Przeprowadzone badania pozwoliły jej skonstruować teorię, która zakładała, że niemowlę w pierwszych miesiącach życia doznaje lęków o charakterze psychotycznym, które wręcz zmuszają ego do wygenerowania mechanizmów obronnych ${ }^{28}$. Dziecko przeżywa strach przed anihilacją, który można utożsamić $z$ freudowskim, pierwotnym popędem śmierci i aby pozbyć się natrętnych lęków dochodzi do rozszczepienia ego. W wyniku rozszczepienia, agresywne treści wynikające z popędu projektowane są na matkę, która staje się dla malca obiektem prześladowczym. Dziecku wydaje się, że matka może zniszczyć w nim całe jego dobro ${ }^{29}$. Stosując metaforę M. Klein, dziecko jedną pierś matki uważa za „dobry obiekt” (ten, który karmi, kocha, zaspokaja), a drugą za "zły obiekt” (ten, który frustruje). To rozszczepienie uczuć dziecka doprowadza do tego, że niemowlę i kocha

22 Tamże, s. 170 - 171.

23 K. Pospiszyl, Przestępstwa..., dz. cyt., s. 16.

24 Tamże.

25 Tamże.

26 Tamże, s. $16-17$.

27 P. Drozdowski, Zaburzenia osobowości. Osobowość antyspołeczna. Wykład dla stuchaczy Krakowskiego Centrum Psychodynamicznego, http://www.kcp.krakow.pl/materialy/zaburzenia-osobowosci, 12.12.2012.

28 M. Klein, Zawiść i wdzięczność oraz inne prace z lat 1946 - 1963, Gdańsk 2007, s. 2.

29 G. Gabbard, Psychiatria psychodynamiczna ..., dz. cyt., s. 47. 
swoją matkę, i jej nienawidzi ${ }^{30}$. Faza, o której mowa nazywana jest „fazą schizoidalno-paranoidalną", z powodu wykorzystywanych przez ego mechanizmów obronnych takich jak: rozszczepienie (,,schizoidalny”) i projekcja („,paranoidalny”) ${ }^{31}$. Jeśli dziecku towarzyszą wyjątkowo silne lęki prześladowcze w pierwszych miesiącach życia, mogą one uniemożliwić pomyślne przejście przez fazę „schizoidalno-paranoidalną”, a także, co za tym idzie, patologiczne rozwiązanie kolejnego etapu - tzw. „pozycji depresyjnej”32.

Pojęcie „pozycji depresyjnej” określa charakterystyczny okres występujący u każdego dziecka przed ukończeniem pierwszego roku życia. W tym czasie zadaniem dziecka będzie połączyć „dobry obiekt” i „zły obiekt” w całość. Niemowlę winno zacząć zauważać, że dobra matka i zła, to nie dwie postaci, a jedna ${ }^{33}$. Pojawiają się ambiwalentne uczucia złości i strachu. Niemowlę kieruje agresywne impulsy w kierunku matki, ale skutkuje to jednocześnie wzrostem lęku (boi się, że utraci matkę) oraz poczuciem winy (chciałem zniszczyć matkę). Doświadczanie smutku przez dziecko, można to nazwać uczuciami depresyjnymi, powoduje integrację wcześniej rozszczepionego ego $0^{34}$. A zatem, „pozycja depresyjna” jest niczym innym, jak doświadczeniem przez dziecko lęku, że jego agresja może uczynić komuś krzywdę ${ }^{35}$. Sytuacja problemowa pojawia się w momencie, gdy w mniemaniu dziecka „złej matki” jest więcej niż „dobrej”. Skutkuje to tym, że nie dochodzi do integracji tych dwóch obiektów, a dla niemowlęcia matka jest zła i frustrująca. Ten niepomyślny przebieg procesu rozwojowego, może spowodować, iż dziecko będzie żyło z nieustanną obawą przed utratą ważnego obiektu, którym później będzie każda bliska osoba. Można to łączyć z permanentnym poczuciem braku miłości, z niską samooceną czy wewnętrznym smutkiem ${ }^{36}$. Taka jednostka, w dorosłym życiu, może sięgać do patologicznych sposobów rozwiązywania „pozycji depresyjnej”. Również do popełniania drobnych przestępstw pod wpływem środków psychoaktywnych, gdyż osoby z nierozwiązaną „pozycją depresyjną” często należą do grupy osób uzależnionych. Traktują alkohol, narkotyki, czy inne używki, jako obiekt zastępczy, zmniejszający ich wewnętrzną depresyjność.

Część psychoanalityków udowadniała, że charakter człowieka kształtuje się dopiero w rozwoju edypalnym. Z. Freud twierdził, że faza edypalna zaczyna się ok. 4 - 5 r.ż., jednak M. Klein upierała się, że wspomniana faza uaktywnia się już między pierwszym, a drugim r.ż. Na czym zatem polega kompleks Edypa? Chłopiec walczy z ojcem o miłość matki ${ }^{37}$. Tata postrzegany jest jako rywal, co wyzwala w dziecku agresję, której źródła możemy szukać jeszcze w fazie oralno-sadystycznej i analno-sadystycznej ${ }^{38}$. Pomyślne rozwiązanie sytuacji edypalnej polega na przegranej dziecka z ojcem. Matka powinna dać odczuć synowi, że to mąż jest jej partnerem. W konsekwencji, przegrane dziecko nie ma innego wyjścia i zaczyna utożsamiać się z płcią ojca.

Niestety, nie zawsze dochodzi do pomyślnego rozwiązania omawianego kompleksu. M. Klein na podstawie analizy zabawy małych dzieci dostrzegła, że każdy chłopiec ma fantazje, że ukradkiem dostaje się do sypialni rodziców i zabija ojca. Towarzyszy mu jednak lęk, że podobnie potraktuje go ojciec (przede wszystkim boi się kastracji). Ponadto, dziecko odczuwa poczucie

30 L. Grzesiuk, Psychoterapia. Praktyka, Warszawa 2006, s. 91.

31 G. Gabbard, Psychiatria psychodynamiczna ..., dz. cyt., s. 47.

32 M. Klein, Zawiść i wdzięczność ..., dz. cyt., s. 3.

33 L. Grzesiuk, Psychoterapia..., dz. cyt., s. 91.

34 M. Klein, Zawisiść i wdzięczność ..., dz. cyt., s. 15.

5 G. Gabbard, Psychiatria psychodynamiczna ..., dz. cyt., s. 48.

6 L. Grzesiuk, Psychoterapia..., dz. cyt., s. 92.

Dziewczynki analogicznie walczą o ojca.

38 M. Klein, Miłość, poczucie winy..., dz. cyt., s. 171 - 172. 
winy, bo tak naprawdę kocha ojca i nie chce go stracić. Marzy jednak o tym, by połączyć się z matka. Mechanizmy obronne pobudzane przez poczucie winy mogą powodować u dziecka wyparcie miłości do matki i okazywanie czułości ojcu, co z kolei często powoduje rozwinięcie się postaw homoseksualnych. Najbardziej niepomyślnym rozwiązaniem konfliktu Edypa będzie sytuacja, w której dziecko separuje się od obojga rodziców - to stanowi kolejną bazę dla rozwoju zachowań antyspołecznych ${ }^{39}$.

Z. Freud był zdania, że przestępczość jest przejawem słabo rozwiniętego sumienia i poczucia winy wynikającego z nieprawidłowego rozwoju psychoseksualnego ${ }^{40}$. Według niego źródła należało szukać w kompleksie Edypa, chociaż we wcześniejszych pracach zwracał uwagę na fazy poprzedzające Edypa: „poczucie winy stanowi wyraz ambiwalentnego konfliktu, odwiecznej walki Erosa i popędu niszczenia czy śmierci" ${ }^{\prime 1}$. Roger Money-Kyrle, podzielając zdanie ojca psychoanalizy, wyróżnił cztery typy przystosowania do życia jednostki, w kontekście towarzyszącemu sumieniu poczuciu winy:

Hipomanik - często się zdarza, że w wyniku niewystarczająco rozwiniętego superego nie posiada poczucia winy bądź znacznie je tłumi. W związku z tym nie odczuwa potrzeby zmiany swojego postępowania. Motywacje altruistyczne są mu obce. Społeczna szkodliwość takiej jednostki jest tym większa, im wyższy jest jej poziom inteligencji. Można powiedzieć, że hipomanik jest „,społecznym drapieżcą". Psychopata, skrajnie antysocjalny i asocjalny, narcyz oraz sadysta.

Styl hipoparanoidalny - największą bolączką tej osoby jest jej silne poczucie winy, które przybiera takie rozmiary, że swoje winy przypisuje innym, aby poczuć się lepiej z samym sobą. Cechuje się dużą dozą agresji, w szczególności werbalnej. Taka jednostka ma tendencje do szukania sobie kozła ofiarnego, wobec którego prezentuje bardzo wrogie postawy. Osoba hipoparanoidalna to projekcjonista, paranoik obsesyjno-kompulsywny, neurotyk.

Postawa autorytarna $-\mathrm{w}$ tym typie również występuje silne poczucie winy, natomiast osoba przejawiająca tę postawę kieruje poczucie winy do wewnątrz. Jednostka jest dla siebie surowa, a każdy popełniony błąd przeżywa bardzo emocjonalnie. Ostatecznie staje się zupełnie niesamodzielna. Woli wykonywać rozkazy i polecenia innych, ponieważ wtedy czuje się zwolniona z odpowiedzialności, a tym samym z poczucia winy. Cały czas szuka wokół siebie osób, które będą w stanie nią pokierować. Taka jednostka jest konformistyczna, cechuje się tępotą umysłową i sztywnością myślenia. Poza tym, bywa wyjątkowo neurotyczna, zależna i odtwórcza.

Typ ludzki (humanista) - ten typ charakteryzuje się konstruktywnym poczuciem winy, bez patologicznego zabarwienia. Dzięki właściwym proporcjom wszystkich trzech składników struktury osobowości, takie ukierunkowanie kompleksu winy powoduje adekwatną ocenę własnych zachowań. Jest to osoba wartościowa społecznie. Nie odrzuca autorytetów, a zarazem zbytnio im nie ulega, zachowując własne zdanie. Altruista, człowiek dojrzały emocjonalnie i spolecznie. Niezależny i twórczy typ ${ }^{42}$.

Kolejne założenie również dotyczyło deficytów w strukturach ego i superego. F. Redl i D. Wineman wyróżnili trzy postaci ego przestępczego:

Całkowity brak superego. Rozwinięte są tylko dwa składniki osobowości, ti. ego i id. Powoduje to upośledzenie moralne, a więc dzieci w tym przypadku nie mają żadnego poczucia winy po dokonaniu czynu przestępczego. Do tej grupy zalicza się dzieci psychopatyczne.

\footnotetext{
39 Tamże.

40 A. Brown, From Individual to Social Defences in Psychosocial Criminology, "Theoretical Criminology" 2003, nr 7, s. 423.

${ }^{41}$ M. Klein, Zawiść i wdzięczność..., dz. cyt., s. 27.

42 K. Pospiszyl, Resocjalizacja nieletnich. Doświadczenia i koncepcje, Warszawa 1990, s. 62 - 63.
} 
Ego zbyt słabe. Takie ego nie może oprzeć się naporowi id, dlatego też dziecko działa pod wpływem chwilowych impulsów. W związku z tym, że w tej grupie przypadków istnieje rozwinięte superego, to po akcie przestępczym pojawia się u takiej osoby poczucie winy, co doprowadza do depresyjnego przygnębienia i kompleksu niższości, dając w dalszej kolejności osobowość neurotyczną. Do tej grupy zaliczamy dzieci nadmiernie lękliwe.

Ego silne. Silne, ale zwichnięte, tj. nakierowane na czyny przestępcze. Cała energia takich dzieci nastawiona jest na to, aby uchronić się od poczucia winy po czynie niezgodnym z oceną rozwiniętego superego $0^{43}$.

M. Klein nie uważała, że zachowania przestępcze wynikają z braku poczucia winy czy ze słabo rozwiniętego superego. Jej zdaniem, jeżeli dziecko popełnia określone czyny zabronione, to musi być to wynikiem zarówno jego wypartych pragnień, jak i potrzebą zostania ukaranym ${ }^{44}$. Co nieoczekiwane, wielu amerykańskich kryminologów zgadza się z teoria, że to właśnie pragnienie kary (wynikające z lęku i poczucia winy - nieświadome aspekty superego), popycha ludzi do popełniania przestępstw ${ }^{45}$. „Dzieci będą przejawiać skłonności aspołeczne i przestępcze oraz przekładać je na działanie (...) i będą to powtarzać tym częściej im bardziej obawiają się okrutnego odwetu ze strony rodziców jako kary za agresywne fantazje skierowane przeciwko nim. Dzieci, które nieświadomie spodziewają się, że zostaną pocięte na kawałki, dekapitowane, pożarte i tak dalej, będą zachowywać się niegrzecznie, by zasłużyć na karę (...). To nie słabość lub brak superego,(...) ale nadmierna surowość superego jest odpowiedzialna za typowe zachowania osób o skłonnościach aspołecznych i przestępczych"46. Z przytoczonych słów M. Klein można wywnioskować, że źródło paranoi i przestępczości jest niemal takie samo. Jednostka aspołeczna może niszczyć innych, ponieważ wydaje jej się, że jest prześladowana. To również sugeruje, że przestępcy są zdolni do uczuć wyższych, a ich czyny przepełnione nienawiścią są jedynie maską dla skrywanej głęboko miłości ${ }^{47}$. Wizja przestępczości M. Klein należy do optymistycznych, bowiem zakłada, że psychoanaliza jest w stanie pomóc jednostkom antyspołecznym. W terapii psychodynamicznej, nawet jeśli pacjent nie chce współpracować, jego niedojrzałe postawy, wobec których broni się struktura ego, pojawią się w przeniesieniu. Przeniesienie jest nieświadomym traktowaniem terapeuty, jako ważnego obiektu z przeszłości (prawdopodobnie figury rodzicielskiej). Podczas procesu pacjent ogrywa kompleks Edypa, często sadystyczne agresje, czy nawet pregenitalne instynkty. W psychoterapii, pacjent zamiast świadomie przypomnieć sobie swoje dziecięce doświadczenia, regresuje się $\mathrm{i}$ odgrywa je w relacji z terapeutą ${ }^{48}$.

Zapoznając się z analizami jednostek antyspołecznych przeprowadzonymi przez psychoterapeutów nurtów psychoanalitycznych oraz biorąc pod uwagę własną praktykę terapeutyczną w placówkach izolacji całkowitej, można wysnuć kilka wniosków dotyczących jednostek antyspołecznych - życie tych osób ukazuje pewien powtarzający się schemat. Osoby silnie antyspołeczne często bywają wyjątkowo inteligentne i czarujące, jednak pomimo tego, nie kończą swojej edukacji. Poszczególne etapy ich życia charakteryzują się hossą bądź bessą. Szybko zdobywają pieniądze, potem równie szybko je tracą. Potrafią się rozwijać i osiagać sukcesy, a następnie niszczyć całe swoje dotychczasowe życie, ulegając desocjalizacji. U większości tych przypadków

43 Tamże, s. $65-67$.

44 M. Klein, Miłość, poczucie winy..., dz. cyt., s. 179.

45 A. Brown, From Individual ..., dz. cyt., s. 423.

46 M. Klein, Miłość, poczucie winy..., dz. cyt., s. 255.

47 Tamże, s. 257.

48 R. Sterba, The Dynamics of the Dissolution of the Transference Resistance, [w:] A. Esman (red.), Essential papers on transference, New York 1990, s. 85. 
występuje uzależnienie od środków psychoaktywnych ${ }^{49}$. Moje spostrzeżenia, wynikające z pracy w zakładach karnych, wykazują także, że jeśli ktoś potrafi się znaleźć „w nieodpowiednim czasie, w nieodpowiednim miejscu” - to właśnie oni. Robią wszystko, by znaleźć się na dnie - tracą pracę, bo przychodzą do niej pijani, zabiera im się dzieci, bo ci trafiają do więzienia, nie kontaktują się z rodzina, bo podobno ktoś im to utrudnia, itd. Wniosek jest istotny - nikt nie potrafi ich tak skrzywdzić, jak oni samych siebie.

Jeśli przyjmiemy, że konkretny przestępca posiada osobowość antyspołeczną ${ }^{50}$ oznacza to, że mamy do czynienia z jednostką psychopatyczną. Klasyczna psychiatria uważa te osoby za nieuleczalne, dlatego „w praktyce najlepiej sprawdza się uznanie zachowań antyspołecznych lub psychopatycznych za prymitywny wariant osobowości narcystycznej” ${ }^{\prime \prime 1}$. Narcyzm jest ideą przynależącą do teorii libido. W klasycznej wersji teorii, libido skierowane jest na własne ego i choć narcyzm nie potrzebuje bezpośredniego wyrażania siebie, to może manifestować się w działalności idealnego ego $0^{52}$, czyli w tak zwanej miłości własnej, która w rzeczywistości podszyta jest niską samooceną. Jak już wcześniej zostało wspomniane, etiologia zachowań antyspołecznych należy do wyjątkowo bogatych. Oprócz ewidentnego powiązania z osobowością narcystyczna, zauważa się także korelację z osobowością borderline oraz z patologią konwersyjną (wariant osobowości histerycznej z zaburzeniami somatycznymi) ${ }^{53}$. Odnosząc się do różnych przyczyn postępowania wbrew prawu, poniżej, na rys. 2., została przedstawiona skala zachowań antyspołecznych i psychopatycznych.

\section{Rys. 2. Skala zachowań antyspołecznych i psychopatycznych.}

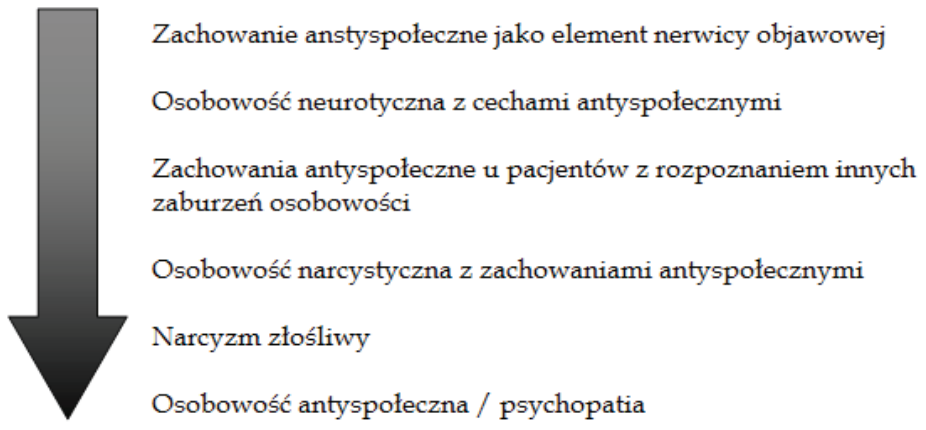

Źródło: G. Gabbard, Psychiatria psychodynamiczna w praktyce klinicznej, Kraków 2009, s. 469.

Najtrudniejsze przypadki - nieuleczalne, znajdują się na dole skali. To jednostki nieposiadające uczuć altruistycznych, kierujące się w relacjach międzyludzkich elementem eksploatacji. Choć nie okazują empatii, doskonale wiedzą czego ludzie potrzebuja, co wykorzystują do realizacji własnych celów. Wyżej umieszcza się narcyzm złośliwy, który niejednokrotnie bliski jest paranoi i sadyzmowi. Obie cechy silnie związane są z ego jednostki. Złośliwi narcyzi po-

49 P. Drozdowski, Zaburzenia osobowości..., dz. cyt.

50 Por.: American Psychiatric Association, Diagnostic and Statistical Manual of Mental Disorders, wyd. IV, Washington 2000.

51 G. Gabbard, Psychiatria psychodynamiczna..., dz. cyt., s. 468.

52 T. Freeman, Some Aspects of Pathological Narcissism, "Journal of the American Psychoanalytic Association" 1964, nr 12 , s. $540-541$.

53 P. Drozdowski, Zaburzenia osobowości..., dz. cyt. 
trafią okazywać ciepłe uczucia, bywają również troskliwi. Kolejna grupa dotyczy osobowości narcystycznych z zachowaniami antyspołecznymi. Takie jednostki nie mają cech sadystycznych, ale wyjątkowo sprawnie manipulują otoczeniem, by osiagnnąc własne cele. Mają jednak na tyle rozbudowane superego, że odczuwają poczucie winy, a popełniane przez nich czyny przestępcze mogą wynikać z nieumiejętności angażowania się w bliskie relacje. Kategoria wyżej dotyczy pacjentów z różnymi zaburzeniami osobowości (np.: osobowością z pogranicza, histrioniczna, paranoiczną i in.), których superego jest znacznie lepiej rozbudowane. Dwie najwyżej położone grupy mogą popełniać czyny antyspołeczne w wyniku poczucia winy ${ }^{54}$. A zatem, $\mathrm{w}$ tym miejscu może okazać się skuteczna, wcześniej omówiona, teoria M. Klein.

Własne doświadczenia w pracy z osadzonymi w zakładach karnych, pozwoliły mi dostrzec nie tylko możliwości, ale także ograniczenia psychodynamiki. Można w tym miejscu powołać się na opinię K. Pospiszyla, który pisze, że „bazujące na psychodynamicznym podejściu strategie oddziaływań resocjalizacyjnych, znajdujące najczęściej zastosowanie w różnych formach terapii indywidualnej, mają jednak także szereg ograniczeń w wypadku zastosowania do przestępców. (...) psychoanaliza (a więc także i całokształt strategii psychodynamicznych) ze swej istoty nie jest odpowiednia do zastosowania u zdecydowanej większości przestępców, stanowi bowiem wytwór ideologii mieszczańskiej klasy średniej. Mentalną osią przedstawicieli tej klasy jest praca nad sobą i stałe doskonalenie wewnętrzne, a wartości te nie są kultywowane przez przedstawicieli niższych warstw społecznych, którzy cechują się ogólnie niższym poziomem potrzeby osiagnięć, z której wypływa typowa dla klas średnich kompulsywna niekiedy dążność do perfekcjonizmu" ${ }^{\prime \prime 5}$. Ponadto, psychoterapia psychodynamiczna już z założenia musi być zawężona, jeśli stosuje się ją w instytucjach totalnych - zwłaszcza w polskich warunkach. Spotkania terapeuty ze skazanym, raz w tygodniu po 45 - 60 minut, przez kilka lat, są niemożliwe choćby z powodów logistycznych czy finansowych. Zakłady karne bywają przeludnione, adaptuje się pomieszczenia administracyjne na cele mieszkalne. Równie doskwierająca jest niewystarczająca liczba wychowawców i psychologów. To wszystko sprawia, że podejście psychodynamiczne w zakładach karnych nie może zaistnieć w takiej formie, jak z innymi pacjentami, w normalnym gabinecie terapeutycznym. Ponadto, psychodynamika okazuje się być mało skuteczna w terapii uzależnień, co oznacza przymus zatrudniania terapeutów różnych podejść.

Co istotne, paradygmat psychodynamiczny oddziela sądy epistemologiczne od innych sądów, czyli przyjmuje sofizmat naturalistyczny, z którego wynika, że „nie sposób z tego, co jest, wywieść to, co być powinno" ${ }^{\prime 56}$. To m.in. wyróżnia podejście psychodynamiczne spośród innych paradygmatów, bowiem psychodynamicy nie tworzą tzw. ideału terapii, nie próbują konstruować czegoś na wzór normy ${ }^{57}$. Uważaja, że to niemożliwe. Zwłaszcza w pracy z jednostkami antyspołecznymi ta zasada wydaje się być szczególnie ważna. Osadzeni w zakładach karnych często charakteryzują się niskim poziomem inteligencji, wykazują się też znikomą zdolnością do refleksji - w tych przypadkach niemożliwa jest terapia psychodynamiczna w swej czystej postaci. Wbrew pozorom, wysoki poziom inteligencji również jest przeszkoda, gdyż inteligentne jednostki antyspołeczne sprawnie manipulują otoczeniem, nie czerpiąc korzyści z terapii, jedynie

54 G. Gabbard, Psychiatria psychodynamiczna ..., dz. cyt, s. 468 - 469.

55 K. Pospiszyl, Sukcesy i pułapki poszczególnych strategii resocjalizacyjnych, [w:] A. Szecówka, B. Koukola, P. Kwiatkowski (red.), Teoria i praktyka resocjalizacyjna wobec wspótczesnych zachowań dewiacyjnych w Polsce i Republice Czeskiej, Wrocław 2008, s. 16.

56 P. Drozdowski, Psychoterapia psychodynamiczna. Wykład dla stuchaczy Krakowskiego Centrum Psychodynamicznego, http://www.kcp.krakow.pl/materialy/psychoterapia-psychodynamiczna, 18.11.2011.

57 Tamże. 
skutecznie przekonują personel, że im się polepsza. Z mojej praktyki zarówno resocjalizacyjnej, jak i terapeutycznej wynika, że w pracy z osobami osadzonymi, najbardziej sprawdza się diagnozowanie problemów jednostki z perspektywy podejścia psychodynamicznego (ze względu na skuteczność tej diagnozy), natomiast rzeczywista praca z wychowankiem powinna opierać się na zasadach behawioralnych. Przestępcy potrzebują jasno określonych zasad, reguł. Muszą wiedzieć czego się od nich oczekuje i w jaki sposób mają te oczekiwania spełniać. W przeciwnym razie - terapia u większość przypadków okaże się nieskuteczna.

Inna kwestia, bardziej poruszająca, zasadza się na osobistych trudnościach terapeuty w pracy z jednostką antyspołeczną. Czyny osadzonych, czasem wyjątkowo drastyczne, nieustannie konfrontują terapeutów z własnymi lękami, czy z wewnętrzną oceną pacjenta. W takich sytuacjach terapeuta nie może być neutralny. Problematyka moralna pobrzmiewa w nim cały czas, tak jak strach, że „kto z kim przystaje, takim się staje”. Należy pamiętać, że klinicysta podczas terapii musi „,skontenerować", czyli pomieścić w sobie całą osobowość pacjenta. Bywa to niebezpieczne, zwłaszcza w pracy z perwersyjnymi jednostkami. Mogą one wywoływać w terapeucie mechanizmy identyfikacyjne, które są najbardziej zagrażając ${ }^{58}$. Głębokie relacje klinicysty $\mathrm{z}$ pacjentem antyspołecznym $\mathrm{w}$ terapii psychodynamicznej, bywają silnie obciążające, dlatego zaleca się częste superwizje. Mają one zapobiec: „psychozie we dwoje”, wybielaniu przestęppy, uważania go za skrzywdzonego przez los, czy wykonywaniu czynności, o które prosi (napisanie wniosku, pochwały, wstawienie się za nim u dyrekcji, itp.).

K. Pospiszyl, który jako jedyny autorytet w Polsce, pisze o wykorzystaniu omawianego paradygmatu w resocjalizacji twierdzi, że „psychodynamiczne podejście psychokorekcyjne zrobiło w resocjalizacji niebywałą karierę i to bynajmniej nie ze względu na jego skuteczność, lecz raczej ze względu na wabiącą niczym śpiew syreni filozofię, na której opiera się ów rodzaj podejścia do resocjalizacji" ${ }^{\prime 59}$. Autor tych słów ma trochę racji. Filozofia psychodynamiczna wabi i zachęca, ale w samej resocjalizacji może być nieskuteczna, gdyż nikt jeszcze, poza Augustem Aichhornem ${ }^{60}$, nie zrobił tak dobrego użytku z teorii psychodynamicznych w ośrodkach resocjalizacyjnych.

Jeśli zawierzyć psychodynamice, wszystko ma swoje wewnętrzne uwarunkowania, toteż jednostki antyspołeczne nie są traktowane w tych teoriach, jako zwyrodnialcy czy degeneraci. Uważa się je raczej za jednostki chore, które potrzebują leczenia psychologicznego i psychiatrycznego. Ich historie, złe doświadczenia, urazy psychiczne, niekochające obiekty, przemoc - wszystko to zapisane jest w ich umysłach. Czują się prześladowani, więc aby tego uniknąc uciekają się do przestępstwa, by chronić swoje ego. Oczywiście, nie należy jednostek antyspołecznych tłumaczyć złym życiem, ciężkimi autobiografiami. Warto jednak dotrzeć do najmroczniejszych aspektów ludzkiego istnienia, aby, jeśli to możliwe, likwidować przyczyny, a nie tylko same rezultaty, jak to czynią inne teorie.

\footnotetext{
BibLIOGRAFIA

Bienenfeld D., Psychodynamic Theory for Clinicians, Philadelphia 2006.

Brown A., From Individual to Social Defences in Psychosocial Criminology, "Theoretical Criminology" 2003, nr 7. Esman A., Essential papers on transference, New York 1990.

Freeman T., Some Aspects of Pathological Narcissism, "Journal of the American Psychoanalytic Association" 1964, nr 12. Gabbard G., Psychiatria psychodynamiczna w praktyce klinicznej, Kraków 2009.
}

58 P. Drozdowski, Perwersje. Wykład dla stuchaczy Krakowskiego Centrum Psychodynamicznego, http://www.kcp.krakow.pl/materialy/perwersje, 25.12.2011.

${ }_{59}$ K. Pospiszyl, Resocjalizacja. Teoretyczne podstawy oraz przyktady programów oddziaływań, Warszawa 1998, s. 52.

60 Por: A. Aichhorn, Wayward Youth, Londyn 1951. 
Greenson G., The Technique and Practice of Psychoanalysis, New York 1967.

Grzesiuk L. Psychoterapia. Praktyka, Warszawa 2006.

Heilbrunn G., Biologic Correlates of Psychoanalytic Concepts, "Journal of the American Psychoanalytic Association" 1979, nr 27.

Klein M., Miłość, poczucie winy i reparacja oraz inne prace z lat 1921 - 1945, Gdańsk 2007.

Klein M., Zawiść i wdzięczność oraz inne prace z lat 1946 - 1963, Gdańsk 2007.

Mitchell S., Black M., Freud and Beyond. A History of Modern Psychoanalytic Thought, New York 1995.

Pospiszyl K., Resocjalizacja nieletnich. Doświadczenia i koncepcje, Warszawa 1990.

Pospiszyl K., Resocjalizacja. Teoretyczne podstawy oraz przykłady programów oddziaływań, Warszawa 1998.

Pospiszyl K., Przestęstwa seksualne, Warszawa 2005.

Pospiszyl K., Sukcesy i pułapki poszczególnych strategii resocjalizacyjnych, [w:] Szecówka A., Koukola B., Kwiatkowski P.(red.), Teoria i praktyka resocjalizacyjna wobec wpótczesnych zachowań dewiacyjnych w Polsce i Republice Czeskiej, Wrocław 2008.

Shedler J., The Efficacy of Psychodynamic Psychotherapy, "American Psychologist" 2010, nr 65.

Sterba R., The Dynamics of the Dissolution of the Transference Resistance, [w:] Esman A. (red.), Essential papers on transference, New York 1990.

Szecówka A., Koukola B., Kwiatkowski P. (red.), Teoria i praktyka resocjalizacyjna wobec wopótczesnych zachowań dewiacyjnych w Polsce i Republice Czeskiej, Wrocław 2008.

\section{Netografia}

Drozdowski P., Perwersje. Wykład dla stuchaczy Krakowskiego Centrum Psychodynamicznego, http://www.kcp.krakow.pl/materialy/perwersje, 25.12.2011.

Drozdowski P., Psychoterapia psychodynamiczna. Wykład dla stuchaczy Krakowskiego Centrum Psychodynamicznego,

http://www.kcp.krakow.pl/materialy/psychoterapia-psychodynamiczna, 18.11.2011.

Drozdowski P., Zaburzenia osobowości. Osobowość antyspołeczna. Wykład dla stuchaczy Krakowskiego Centrum Psychodynamicznego,

http://www.kcp.krakow.pl/materialy/zaburzenia-osobowosci, 12.12.2012.

\section{STRESZCZENIE}

Celem artykułu jest przybliżenie czytelnikowi założeń paradygmatu psychodynamicznego. Rozważania zakładają również, że psychodynamika może być skuteczna w ustalaniu przyczyn różnorodnych form dewiacji, bowiem na podstawie indywidualnych biografii oraz neuroscience analizuje takie pojęcia, jak: poczucie winy, strach przed przestępczością czy sumienie.

Słowa kluczowe: psychodynamika, paradygmat psychodynamiczny, psychoanaliza, Zygmunt Freud, zachowania antyspołeczne, przestępczość.

\section{A Psychodynamic Study of Antisocial Behaviours}

\section{Summary}

The aim of this paper is to introduce the reader to the main tenets of psychodynamics. It also argues that psychodynamic approaches can be effective in determining the causes of various forms of deviance, because on the basis of individual biographies, neuroscience enables us to analyze such concepts as guilt, a fear of crime and conscience.

Key words: psychodynamics, psychodynamics paradigma, psychoanalysis, Sigmund Freud, antisocial behavior, crime 